\title{
A Providência Divina e o Homem de Bem
}

\section{Luiz Otávio Pereira Coppieters}

Orientador: Moacyr Novaes

Bolsa: na época da apresentação deste, 2002 no SIICUSP, não possuía bolsa.

Este trabalho tem por objetivo a investigação dos termos da pergunta feita por Lucílio que suscita a escrita do tratado De Prouidentia por Sêneca, a saber, "Por que, se a Providência Divina rege o mundo, tantos males atingem os homens de bem?"1. Esta encerra três termos centrais para uma posterior discussão acerca do próprio tratado. Os termos são: a Providência Divina, o Homem de Bem e as adversidades. Aqui trataremos, inicialmente, de fazer uma breve exposição acerca da filosofia estóica naquilo que nos interessa, em seguida, colocaremos à vista quais conceitos os termos envolvem e, por fim, rearranjaremos a pergunta, permitindo assim uma resposta realmente pertinente.

$\mathrm{Na}$ filosofia estóica termos como Logos, Deus e Natureza são sinônimos, representam o mesmo conceito. São termos que se confundem com o mundo, pois representam tudo aquilo que nele existe. De acordo com Diógenes Laércio,

eles chamam natureza quer ao que o mundo contém quer ao que produz as coisas terrestres. A natureza é uma maneira de ser que se

${ }^{1}$ Sêneca. Sobre a providência divina, p. 19. 
move por si mesma segundo as razões seminais, produzindo e contendo as coisas que nascem dele em tempos definidos e formando coisas semelhantes àquelas donde foi destacada.

Em primeiro lugar, temos uma definição de natureza constituída de coisas (os corpos) e de regras que as organizam. Em segundo lugar, a idéia da existência de razões seminais que se disseminam em todas as coisas implica a existência de um mundo entendido como organismo, no qual todas as coisas operam segundo as mesmas leis e para os mesmos fins. As coisas no mundo são permeadas pelo lógos spermatikós, o sêmen racional, cuja fonte e constituição é Deus. Essa disseminação da razão divina nos objetos tem a função de assegurar a unidade do organismo formado pelo mundo. Desta forma, pode-se dizer que o mundo é um organismo vivo, como um indivíduo, assim como o homem por exemplo.

Neste organismo cada coisa está em harmonia, seja consigo mesma, seja com outras coisas, seja com o todo. A harmonia do organismo mundo é a expressão da natureza divina. O nome dado a esta harmonia, a esta unidade coordenada que sustém o organismo mundo, é simpatia universal.

\section{De acordo com Jean Brun,}

a teoria da simpatia universal tem não só um alcance físico, na medida em que coroa uma teoria da causalidade, mas também um alcance metafísico e ético. Um alcance metafísico na medida em que, uma vez que a simpatia das coisas não exprime senão a presença total de Deus num mundo que se reduz, no fundo, a este Deus, esta simpatia fundada em Deus e por Deus, implica um finalismo da natureza que supõe os benevolentes desígnios de uma providência onipotente. (...) Um alcance ético, na medida em que a vida do sábio será uma vida que terá sabido pôr a harmonia em si mesma e manter-se em simpatia com o universo de que participa. ${ }^{2}$

Temos aqui três dimensões nas quais a simpatia universal opera: física, metafísica e ética. Da primeira, a física, decorre uma teoria

2 Jean Brun. O estoicismo, p. 54. 
da causalidade que se exprime na ligação intrínseca de cada coisa no mundo. Estas coisas estão relacionadas causalmente porque tudo no mundo é matéria, ou seja, tudo é engendrado em uma só substância. A segunda, a metafísica, diz respeito ao campo e à ação da divindade com relação ao mundo. A simpatia universal foi posta por Deus em seu interior com a finalidade de manter-se como tal, por isso a idéia de organismo. Ou seja, deus age em si mesmo, este é seu campo de atuação. E a Providência Divina exprime a vontade divina nas leis que regem o mundo. Evidentemente, estas regras são necessariamente benévolas, pois deus não conteria nada em si que pregaria sua destruição. A maior prova disto são que as coisas estão aí, o mundo. Por fim, a ética, que envolve a ação daquele homem cuja autonomia se expressa na vida em acordo com a natureza, isto é, uma conduta harmônica consigo mesma e com o mundo.

Neste destaque da filosofia estóica, podemos perceber muito do papel da providência no mundo, já que o termo providência se identifica com natureza. Segundo Jean Brun, "a providência exprimese na simpatia universal que une os seres entre eles e no desenrolar dos acontecimentos em que se traduz a vida no mundo" ${ }^{3}$ Ou seja, a providência é responsável pela ordenação do mundo e pela sua união enquanto organismo. É a reguladora e as próprias leis do mundo. É aquilo a que todos os seres estão submetidos, a razão universal, já que todos são por ela permeados. Com efeito, a Providência Divina não é algo externo que impõe o modo com o qual as coisas devam operar. Pelo contrário, atua no interior dos corpos de forma a manter a causalidade necessária dos acontecimentos que, no todo, engendram o bem, finalidade última. Portanto, ela é causa imanente de todos os fenômenos. Como Sêneca afirma na Epístola 65, em que se trata de uma discussão acerca dos "princípios dos quais tudo deriva"4 "A

3 Idem, p. 60.

${ }^{4}$ Epistola 65, 2. 
divindade é que regula tudo, e tudo a rodeia e segue como a um guia ou um chefe."

Da mesma forma que há coisas que seguem as regras da Providência, há seres que conscientemente seguem as determinações da natureza. Estes últimos são os homens de bem. E sobre ele falaremos agora. Sobre sua constituição, sua maneira de agir e o seu papel na ordem universal.

Assim como os demais homens, o homem de bem é um corpo animado por uma alma. Esta alma é um sopro ígneo, um fogo artesão, um tênue ar que anima um corpo. A alma é uma pequena parte da razão universal. Ela é a responsável pela possibilidade do homem de se harmonizar com o universo, com a razão universal, pois se trata de uma e mesma coisa, só que em dimensōes reduzidas. Com efeito, a razão do homem, a alma, tem a possibilidade de, ao se identificar com a razão da qual faz parte, entender o sentido da simpatia universal. E o homem de bem é aquele que consegue utilizar sua razão de modo adequado para tal tarefa. Aquele que consegue viver em acordo com a natureza, consegue, com efeito, entrar em sintonia seja consigo mesmo seja com o mundo.

O homem de bem, enquanto indivíduo, é um microcosmo que funciona do mesmo modo que o mundo. Assim como este último está em harmonia com suas partes constituintes, o homem de bem está em harmonia com as suas. Contudo, por ser parte do macro-cosmo, o homem de bem também está em harmonia com as demais coisas que não ele mesmo. E aqui se dá a diferença para com o mundo: é exigido dele uma forma de agir capaz de manter a harmonia consigo mesmo e com as coisas externas.

Como vimos, o homem de bem se diferencia dos demais homens pelo uso da razão. Ele a utiliza tendo em vista o mesmo fim que a razão universal, ou seja, o bem. Ou seja, ele é uma pequena parte do todo que age virtuosamente.

${ }^{5}$ Ep. 65, 23-4. 
O único bem é a virtude, não existe bem onde não existe virtude $\mathrm{e}$ quanto à virtude diremos que ela reside na melhor parte de nós mesmos, ou seja, na parte racional. A virtude não é outra coisa senão a faculdade de ajuizar de uma forma correta e imutável; dessa faculdade provêm as decisões da vontade, e graças a ela se clarifica a natureza de todas as formas que despertam a vontade. De acordo com essa faculdade é legítimo considerar como bem, - e como bens iguais sobre si - tudo aquilo que existe a presença da virtude. ${ }^{6}$

Quando Sêneca afirma que é da faculdade da virtude que provêm as decisões da vontade, entende-se que o homem de bem, que é quem se utiliza desta faculdade, submete suas vontades ao seu juízo. Ou seja, esse homem desejará apenas aquilo que a virtude considerar digno de ser desejado. Assim é, portanto, a forma de agir empregada pelo homem de bem. Esta forma de agir envolve, de um lado, a filosofia como meio de sublimar a razão e, de outro, o desapego às coisas materiais, pois estas são intrinsecamente ligadas às paixões, à passividade. A filosofia, de cunho libertário, tem caráter propedêutico no sentido de que é quem possibilita um aprendizado para uma reta conduta. Cito Sêneca na Epístola 16:

o objetivo da filosofia consiste em dar forma e estrutura à nossa alma, em ensinar-nos um rumo na vida, em orientar nossos atos, em apontar-nos o que devemos fazer ou pôr de lado, em sentar-se ao leme e fixar rota de quem flutua à deriva entre escolhos. Sem ela ninguém pode viver sem temor, ninguém pode viver em segurança. ${ }^{7}$

Ou seja, a filosofia é, acima de tudo, prática. Tem como fim atividades que elevem a condição humana. Em contrapartida, as coisas materiais representam apenas desejos imediatos, apegados a coisas passageiras. O homem que a elas se liga está susceptível à passividade, pois estar-se-á ligando a coisas de duração reduzida no tempo e passíveis de serem arrebatadas. Nelas não há qualquer estabilidade que

${ }^{6}$ Ep. 71, 32-3.

7 Ep. 16, 3. 
garanta o mínimo de segurança para uma vida ideal. Com efeito, sua adesão reduz o homem ao campo da passividade onde reina a fortuna, o acaso. Cito a Epístola 71,

os bens do corpo são de fato bens para o corpo, mas não são bens de valor absoluto; tais bens podem ter algum valor, mas carecem de dignidade; entre eles existem consideráveis diferenças, uns são mais valiosos outros menos. ${ }^{8}$

A desmedida das coisas corporais apenas desvia o homem do fim ao qual poderia dirigir-se voluntariamente.

As adversidades têm sua morada no reino da fortuna. A adversidade opera apenas no campo material, se apresentando como um acontecimento sem causa que imprime nos homens uma dor, seja física, seja psicológica. Contudo, as adversidades de fato atingem os homens. Mas não os de bem. Ora, estes últimos são guiados unicamente pela razão, encontrando-se em harmonia consigo mesmos e com o mundo. Com efeito, ele não tomará a adversidade como sendo algo inesperado ou mesmo como um mal. O homem de bem é cônscio de que tudo aquilo que com ele se passa está a cumprir um papel designado pela Providência Divina, portanto tendo como fim o bem. Como afirma Sêneca na Epístola 71, "todas as adversidades merecerão até $o$ nome de bens desde o momento em que a virtude lhe confira valor moral." É a virtude que permite ao homem de bem não tomar como mal aquilo que um homem comum chama de adversidade. A virtude permite ao homem de bem distinguir se o que se passa depende dele ou não. Em ambos os casos ele é ativo, pois, se depender dele, tomará a atitude virtuosamente correta na tentativa de manter a concordância com a natureza, se não, ele a suportará com calma e serenidade - características próprias do sábio. Assim sendo, não haverá sofrer, nem passividade. A aparência dos fatos não o conduzirá.

\footnotetext{
${ }^{8}$ Ep. 71, 33.

${ }^{9}$ Ep. 71, 6.
} 
Desta forma, o entendimento dos critérios constitutivos do homem de bem e da Providência Divina são suficientes para a compreensão do que é adversidade de fato. Portanto, entendido que a Providência Divina é a própria forma com a qual o mundo se arranja e que a ela nada escapa, e também que a idéia de Homem de Bem, de Sábio, não envolve qualquer passividade, restará à adversidade o papel de ludibriar aqueles que não compreendem o funcionamento da razão, fazendo com que esses homens não alcancem a beatitude. Aliás, o que permite uma vida ativa e feliz é a filosofia. A identificação da ação do sábio com o sentido da Providência Divina, que é a liberdade da razão, ou seja, a felicidade, passa, pois, por um processo no qual a filosofia exerce papel primordial.

Podemos nos arriscar a reformular a pergunta da seguinte maneira: por que não é adversidade aquilo pelo que o homem de bem passa? Para tanto, devemos nos embrenhar na investigação do próprio papel que a filosofia desempenha. E Sêneca o anuncia na Epístola 16:

Tenho a certeza, Lucílio, que é para ti uma verdade evidente que ninguém pode alcançar uma vida, já não digo feliz, mas nem sequer aceitável sem praticar o estudo da filosofia; além disso, uma vida feliz é produto de uma sabedoria totalmente realizada, ao passo que para ter uma vida aceitável basta a iniciação filosófica. ${ }^{10}$

\section{Bibliografia}

ANDRÉ, J.-M. "Otium et vie contemplative dans les Lettres a Lucilius". Revue des Études Latines, Paris, 40e. année, 1963.

BRUN, J. O estoicismo. Lisboa: Edições 70, 1986.

GRIMAL, P. Sénèque: sa vie, son ouvre, avec un exposé de sa philosophie. Paris: Presses Universitaires de France, 1948.

${ }^{10}$ Ep. 16, 1. 
. Sénèque, ou l'a Conscience de l'Empire. Paris: Fayard, 1991.

GUARINELLO, N. L. "Nero, o Estoicismo e a Historiografia Romana". Boletim do CPA, Campinas, n. 1, jan./jul., 1996.

GUILLEMIN, Mlle. A. "Sénèque directeur d'ames I: l'idéal" Revue des Études Latines, Paris, 30e. année, 1953.

. "Sénèque directeur d'ames II: son activité pratique". Revue des Études Latines, Paris, 31e. année, 1954.

PEREIRA, M. H. da R. "Cultura Romana". In: Estudos de História da Cultura Romana. v. II. Lisboa: Fund. Calouste Goulbenkian, 1984.

SÊNECA, L. A. Sobre a providência divina. Trad. R. C. Lima. São Paulo: Ed. Nova Alexandria, 2000. 